\title{
Judicial Meetings with Children in Australian Family Law Proceedings: \\ Hearing Children's Voices
}

\author{
by \\ Michelle Meilin Fernando \\ BA, LLB(Hons), Grad Cert Legal Prac
}

Submitted in fulfilment of the requirements for the Degree of Doctor of Philosophy

University of Tasmania, July 2011 


\section{Declarations}

\section{Declaration of Originality}

This thesis contains no material which has been accepted for a degree or diploma by the University or any other institution, except by way of background information and duly acknowledged in the thesis, and to the best of the my knowledge and belief no material previously published or written by another person except where due acknowledgement is made in the text of the thesis, nor does the thesis contain any material that infringes copyright.

Signed:

Dated:

Michelle Meilin Fernando

\section{Authority of Access}

This thesis may be made available for loan and limited copying in accordance with the Copyright Act 1968.

Signed:

Dated:

Michelle Meilin Fernando

\section{Statement of Ethical Conduct}

The research associated with this thesis abides by all international and Australian codes on human and animal experimentation. Research conducted under this study received approval from the Human Research Ethics Committee (Tasmania) Network which is constituted under the National Health and Medical Research Council.

Signed:

Dated:

Michelle Meilin Fernando 


\section{Abstract}

Australian family law judicial officers rarely take the opportunity to meet with children who are the subject of proceedings, despite the fact that the outcome of these proceedings will affect many important aspects of a child's life. This appears to be at odds with the court's obligation to regard the best interests of the child as the paramount consideration and the child's right to participate pursuant to the United Nations Convention on the Rights of the Child. While it appears that the practice of judicial meetings with children is not encouraged in Australia, internationally there is growing support. Several countries have implemented guidelines or taken other steps to actively encourage greater use of the practice. In some countries, judicial meetings are carried out frequently, uncontroversially and successfully. Delegates at the $5^{\text {th }}$ World Congress on Family Law and Children's Rights in 2009 passed a resolution in support of judges considering whether to meet with a child in every case before them.

This thesis looks at the benefits that can be gained, both for children and for decisionmaking, by judges meeting with children. These benefits are viewed within the wider context of how the right of children to express their views is exercised in family law matters and the literature on how children feel about their current level of participation in court proceedings. In determining what is in the best interests of a child, judges may be aided by a practice that enables them to learn more about a child's needs and interests than via other recognised methods of hearing children's views.

The thesis explores the reasons why there are only a handful of cases in which Australian judges have met with children and discusses the main criticisms of the practice. The author conducted a unique empirical study to discover the views and experiences of the Australian family law judiciary about meeting with children. Utilising both qualitative and quantitative methods, the study involved in-depth interviews with four Family Court judges and a survey of all family law judicial officers in Australia. The results of the study make an original contribution to the field of judicial attitudes to children's participation in family law. It was discovered that some problems discussed in the literature, such as due process and confidentiality, may be more perceived than real as judges were able to suggest ways to overcome them. The study found that many judges see strong benefits in meeting 
with children, but that they may be unable to overcome two lingering concerns. Judges perceive that they lack the skills and training to meet with children, and they are troubled by the prospect that judicial meetings may subject children to parental pressure or manipulation.

The thesis makes recommendations to ensure greater certainty in the practice of judicial meetings with children. These include the implementation of Australian guidelines on when and how judicial meetings should be conducted. With recent child-focused changes to family law and practice, such as the Less Adversarial Trial procedure, and growing international discussion, it is anticipated that judicial culture may slowly change. With time, judges may consider the potential benefits of meeting with a child in every case that comes before them. It is argued that it is imperative they do so in order to give effect to the internationally recognised rights of children and the fundamental obligation of the family law courts to regard the best interests of the child as the paramount consideration. 


\section{Acknowledgements}

I owe a debt of gratitude to my supervisors extraordinaire, Professor Margaret Otlowski and George Zdenkowski. Their never-ending support, enthusiasm, suggestions and encouragement in all matters went above and beyond the call of duty. I am also very grateful to the Honourable Justice Robert Benjamin of the Family Court of Australia, who made time in his busy life to listen to my ideas and offer advice on numerous occasions. I was extremely lucky to have the support of these three learned professionals.

I wish to acknowledge and thank the numerous academics, practitioners and judges, both in Australia and overseas, who donated their time to discuss my research, answer questions, offer advice and share ideas. In particular, I wish to thank:

From Canada: Associate Professor Rachel Birnbaum, University of Western Ontario; The Honourable Mr Justice George Czutrin and the Honourable Madam Justice Goodman, Superior Court of Justice, Ontario; Martha McCarthy, Principal and Heather Hansen, Lawyer, Martha McCarthy \& Company, Toronto.

From the United Kingdom: Julius Brookman, Lawyer, Brookman Lawyers, London; District Judge Nicholas Crichton, Inner London Family Proceedings Court; Mavis Maclean and Dr Robert George, Oxford University; Professor Fiona Raitt, University of Dundee.

From New Zealand: Principal Judge Peter Boshier and Judge Robert Murfitt, Family Court of New Zealand; Associate Professor John Caldwell, Canterbury University; Murray Cochrane, Senior Partner, Billings Lawyers, New Plymouth; Associate Professor Pauline Tapp, University of Auckland; Dr Nicola Taylor, Centre for Research on Children and Families, University of Otago.

From Israel: Dr Tamar Morag, Center for Children and Youth.

From Australia: Associate Professor Juliet Behrens, Australian National University; Associate Professor Judy Cashmore, University of Sydney; Dr Robyn Fitzgerald, Southern Cross University; Nicola Ross, University of Newcastle.

I acknowledge the support of the Family Court of Australia, the Federal Magistrates

Court of Australia and the Family Court of Western Australia for agreeing to allow me to survey their judicial officers and assisting with the survey's distribution. Special thanks to the Honourable Justice Stephen Thackray, Chief Judge of the Family Court of Western Australia. 
I thank the four judges of the Family Court of Australia who agreed to be interviewed about their views and experiences of meeting with children. I am grateful for their time, candour and insightful comments, which gave depth and colour to this research.

I acknowledge receipt of the Sir Henry Baker Memorial Fellowship, the McDougall Postgraduate Scholarship, the Andrew Inglis Clark Scholarship in Law and History and the Neasey Scholarship in Law, administered by the University of Tasmania. These scholarships enabled me to travel both interstate and internationally to attend conferences and speak with fascinating people. I thank the donors and the selection committees.

I acknowledge the generous support of the Faculty of Law at the University of Tasmania. This thesis could not have been possible without the funding and resources of the faculty and the encouragement of its members. I acknowledge receipt of a Faculty of Law Postgraduate Scholarship, which enabled me to engage in full-time study for several years. Special thanks to Professor Don Chalmers, Dr Lisa Butler, Dr Sam Hardy, Dr Mark Stranger, Dr Olivia Rundle, Dr Jeremy Prichard, Professor Gino Dal Pont and (soon to be Drs) David Plater and Patrick Foong for their friendship, support and assistance.

Finally, thank you to my wonderful family and friends who were, and continue to be, unfailing in their belief of my abilities. Many thanks to my army of talented proofreaders: Gosia Kaszubska, Hilary Bugg, Jayne Gyton and, in particular, Doug Edmonds for his expert skills and for the many hours he spent with this document. Special thanks to my husband Will for believing in this thesis, for being a helpful sounding-board, for teaching me that spreadsheets can be used for the forces of good and for being cheerful in the face of adversity.

My late father Dr Patrick Fernando AM, child and adolescent psychiatrist, was a helper of families in crisis, a fighter for the rights of children, a great believer in the value of higher education, and a fantastic dad. This thesis is dedicated to his memory. 


\section{Table of Contents}

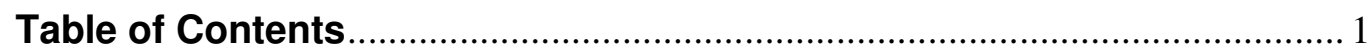

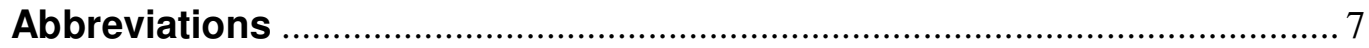

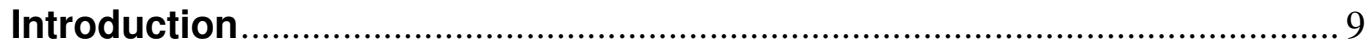

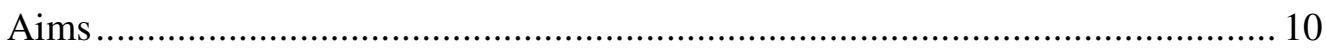

The demise of rule 15.03 of the Family Law Rules 2004 (Cth).......................... 11

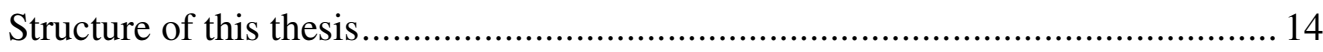

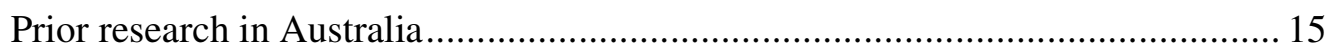

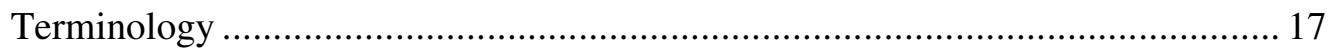

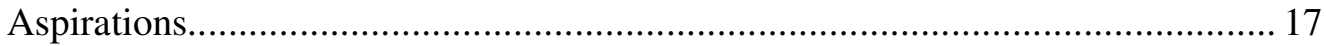

Chapter One: The court's role in making decisions for children ............. 19

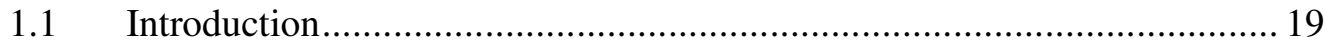

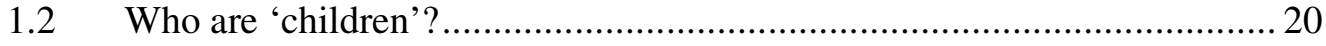

$1.3 \quad$ Parental separation in Australia .................................................... 20

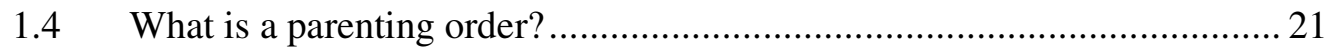

1.5 How arrangements for children are made.......................................... 21

1.5.1 Parental responsibility ...................................................... 21

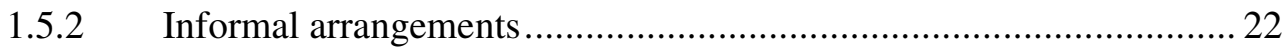

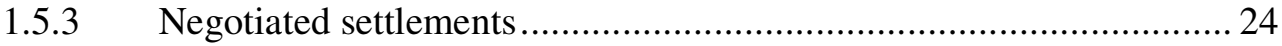

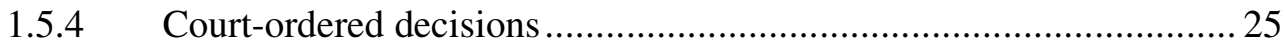

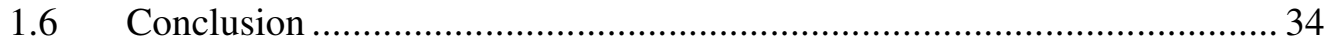

Chapter Two: Why it is important for judges to listen to children........... 37

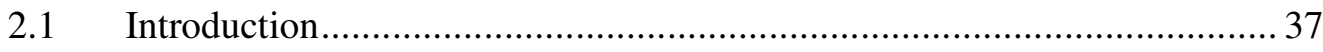

2.2 The child's right to be heard and express their views pursuant to Article 12

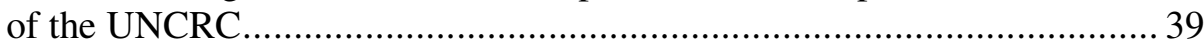

2.2.1 Background to the UNCRC ....................................................... 40

2.2.2 Rights granted to children ................................................ 42 
2.2.3 Tension between children's right to participate, the 'best interests' principle and protection rights ................................................... 43

2.2.4 The meaning of Article 12 and the rights it grants to children........... 45

2.2.5 The effect of the UNCRC in Australian domestic law .....................49

2.2.6 Legitimate expectation UNCRC will be complied with ...................51

2.2.7 The effect of Article 12 for children who are the subject of family law proceedings........................................................................... 53

2.3 The legislative requirement to take children's views into account .............55

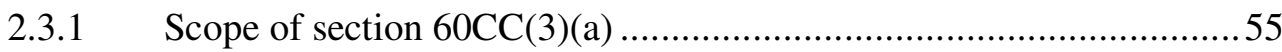

2.3.2 Failure to implement Article 12 of the UNCRC..............................63

2.3.3 How $\operatorname{s60CC(3)(a)~is~treated~by~the~court~.........................................64~}$

2.4 Children's desire to be heard and participate in decision-making, and the

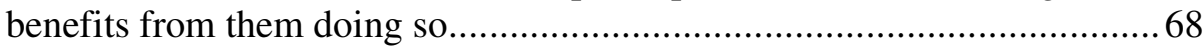

2.4.1 Children's desire to be involved in decision-making .......................69

2.4.2 Children's capacity to participate and communicate effectively.........71

2.4.3 Children benefit when they feel involved in decision-making............73

2.4.4 'Having a say' does not mean deciding ........................................ 76

2.4.5 Benefits of children's participation for decision-making...................79

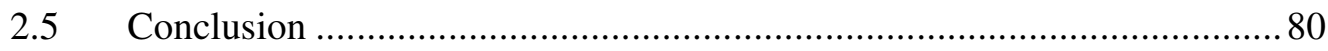

Chapter Three: How judges hear children's views ................................. 83

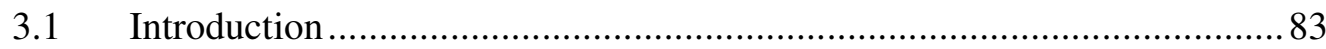

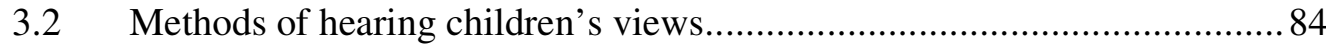

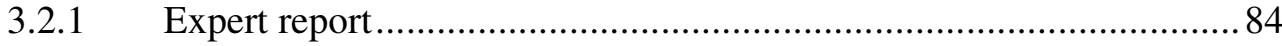

3.2.2 Independent Lawyer for the Child ............................................ 90

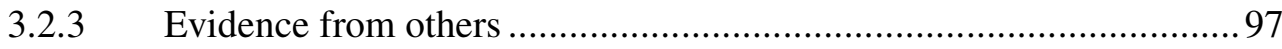

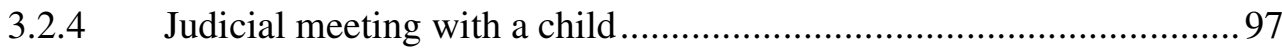

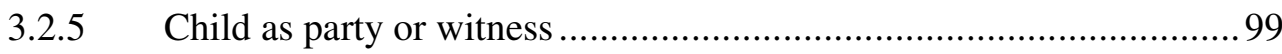

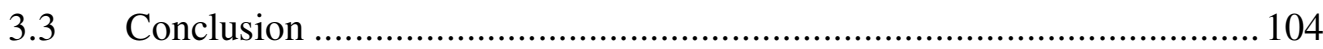


Chapter Four: Why judges should meet with children ......................... 105

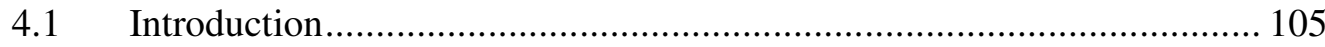

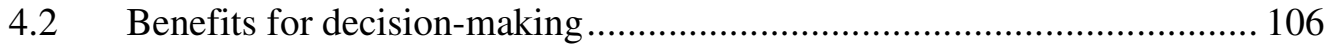

4.2.1 Hearing evidence directly ....................................................... 106

4.2.2 Obtaining children's views in cases of urgency .......................... 111

4.2.3 Exploring options with the child ................................................ 112

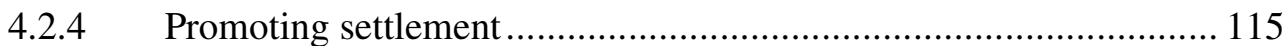

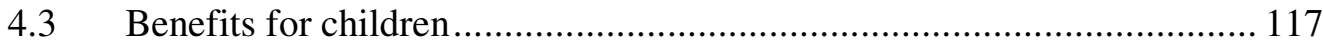

4.3.1 Children want to meet with judges .......................................... 117

4.3.2 Acknowledging the child's right to be heard ................................ 123

4.3.3 Explaining orders to a child ................................................. 125

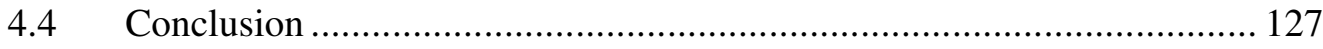

Chapter Five: Why Australian judges do not meet with children .......... 129

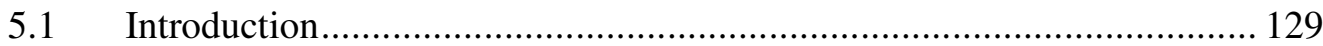

5.2 Detriments of judicial meetings as identified in the literature .................. 130

5.2.1 Due process and confidentiality ............................................ 131

5.2.2 Judges are not trained to speak with children .............................. 135

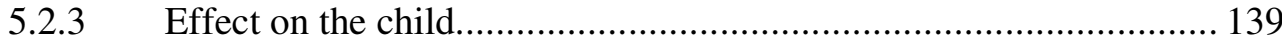

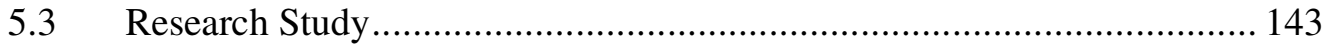

5.3.1 Previous study in Australia ..................................................... 144

5.3.2 Interviews with four FCA judges ............................................. 147

5.3.3 Survey of Australian family law judicial officers .......................... 161

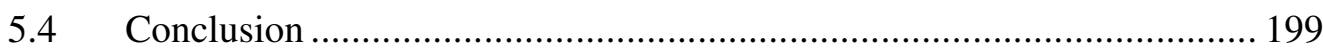

Chapter Six: How judges hear children's views in other jurisdictions.. 201

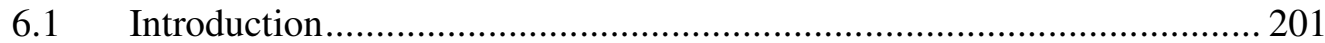

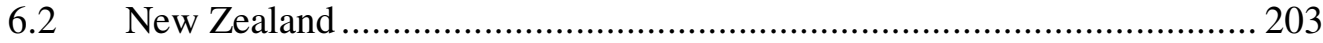

6.2.1 The Family Court of New Zealand.............................................. 204 


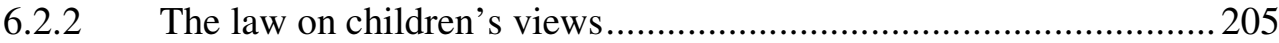

6.2.3 How the FCNZ hears children's views ........................................ 208

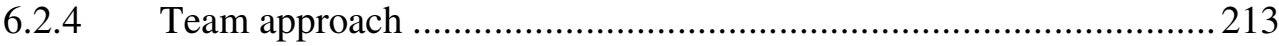

6.2.5 The popularity of judicial meetings with children in New Zealand ..216

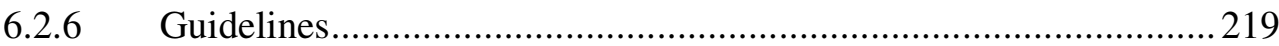

6.2.7 How have concerns about judicial meetings with children been

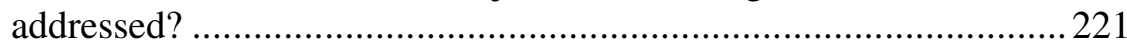

6.2.8 Commentary on New Zealand law and practice.......................... 227

6.3 United Kingdom (England and Wales).............................................. 231

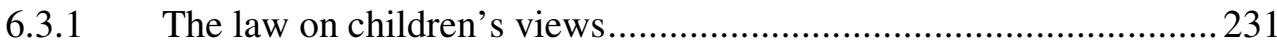

6.3.2 How the court hears children's views ........................................2233

6.3.3 How judges speak with children in England and Wales................. 238

6.3.4 Jurisdiction and lack of continuity ............................................24

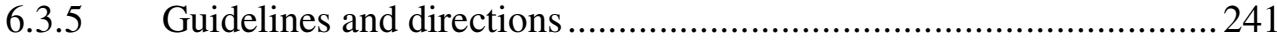

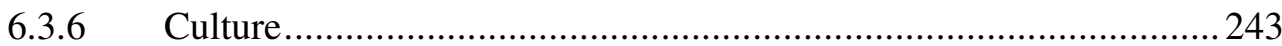

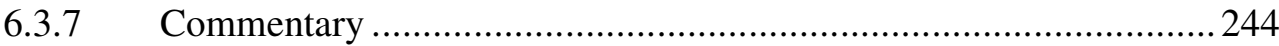

6.4 United Kingdom (Scotland) ............................................................ 245

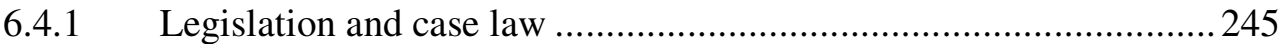

6.4.2 Hearing children's views............................................................ 247

6.4.3 How judges speak with children in Scotland .............................. 248

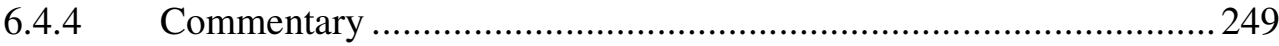

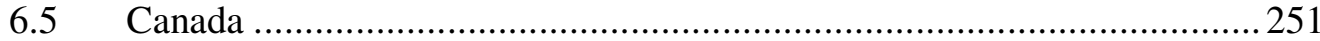

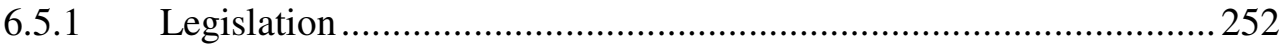

6.5.2 How the court hears children's views ............................................ 253

6.5.3 Incidence of judicial meetings with children in Ontario................... 258

6.5.4 How judges speak with children in Ontario .................................. 261

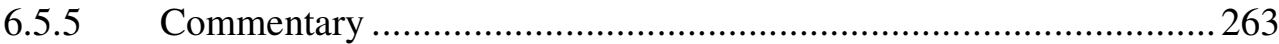




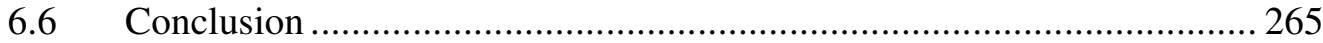

Chapter Seven: Recommendations and conclusions ........................... 269

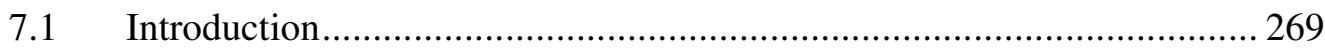

7.2 Amendments to the Family Law Act 1975 (Cth)................................. 269

7.2.1 Incorporating Article 12 of the United Nations Convention on the Rights of the Child....................................................................... 269

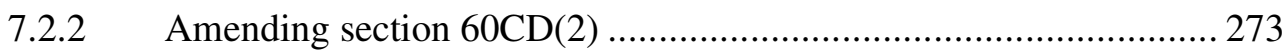

7.3 Guidelines for judges meeting with children .................................... 274

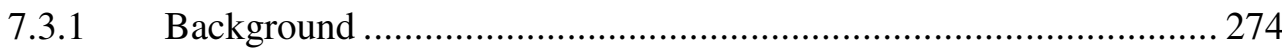

7.3.2 Explanation of the draft guidelines......................................... 277

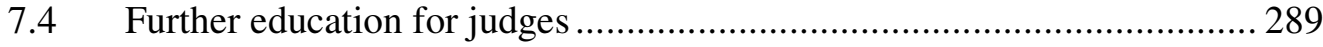

7.4.1 Benefits to children in being involved in decision-making. ............. 290

7.4.2 Speaking with children and interpreting their views ...................... 291

7.5 Study of outcomes for children and judges ..................................... 292

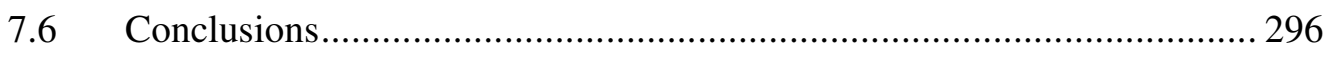

Appendix One: Selected Articles from the United Nations Convention on the

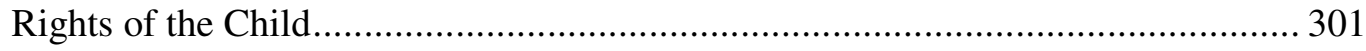

Appendix Two: Information sheet for interviews with four FCA judges ............ 311

Appendix Three: Information sheet for survey of Australian family law judicial

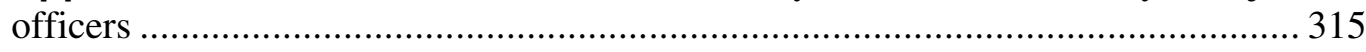

Appendix Four: Survey of Australian family law judicial officers ................... 317

Appendix Five: Draft Guidelines for Judicial Meetings with Children............... 325

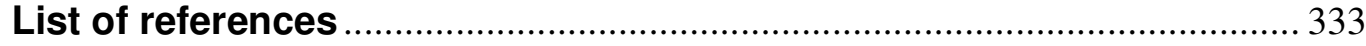

